\title{
A semiochemical from brood cells infested by Varroa destructor triggers hygienic behaviour in Apis mellifera
}

\author{
Francesco NAZZI*, Giorgio Della Vedova, Mauro D’Agaro \\ Dipartimento di Biologia Applicata alla Difesa delle Piante, Università di Udine, via delle Scienze 208, \\ 33100 Udine, Italy
}

(Received 27 January 2003; revised 3 April 2003; accepted 14 July 2003)

\begin{abstract}
Hygienic behaviour of bees towards mite infested brood is involved in the tolerance of some bee strains to Varroa destructor. The stimuli triggering hygienic behaviour are olfactory cues emanating from cells containing infested brood but their identity is still unknown. After confirming the capacity of bees to detect and empty mite-infested cells, we studied the volatile chemicals released by artificially infested worker brood cells by means of SPME-GC-MS. The identified chemicals were then bioassayed by comparing the bees' hygienic behaviour towards treated cells into which $1 \mu \mathrm{g}$ of each compound was injected and control cells which received the solvent alone. Z-(6)-pentadecene significantly increased the number of cells emptied by the bees.
\end{abstract}

Varroa destructor / semiochemicals / hygienic behaviour / removal / hydrocarbons

\section{INTRODUCTION}

Tolerance of honeybees to Varroa destructor Anderson \& Trueman is receiving increasing attention (Spivak and Boecking, 2001). Tolerance is related to several factors, among which honey bee hygienic behaviour towards mite infested brood plays a significant role (Boecking and Spivak, 1999). For this reason, research aimed at the identification of the stimuli causing this behaviour has been conducted by several researchers.

The stimuli triggering hygienic behaviour are most likely olfactory cues emanating from cells containing diseased brood (Boecking and Spivak, 1999) but their identity is still unknown. Stimuli coming from both the mite and the brood have been considered in previous research. Results presented by Aumeier and Rosenkranz (2001) and Martin et al. (2001, 2002) suggest that polar compounds from the mite cuticle may trigger hygienic behaviour. Spivak and Downey (1998) and Gramacho et al. (1999) showed that body fluid from bee brood is a strong stimulus for the bees to remove treated pupae.

Selection programmes for breeding tolerant bees need effective methods for checking bees or bee colonies for the presence of specific traits. At present, hygienic behaviour of bee colonies is assessed by means of time-consuming behavioural assays (Spivak and Gilliam, 1998). Masterman et al. (2001) showed that this trait is correlated to the response of bees to olfactory stimuli from diseased brood. If the semiochemicals triggering hygienic behaviour were identified, simpler bioassays to check bees or bee colonies for their ability to detect infested brood cells could be developed.

The aim of this research was to verify the existence of, and then identify the chemical stimuli that induce hygienic behaviour of bees towards mite infested cells.

\footnotetext{
* Corresponding author: francesco.nazzi@ pldef.uniud.it
} 


\section{MATERIALS AND METHODS}

\subsection{Biological materials}

Local Apis mellifera L. colonies maintained in Udine (northeastern Italy) were used. $V$. destructor mites used in all the experiments were taken from local colonies; they were obtained from brood cells capped in the preceding 0-15 hours (Chiesa et al., 1989).

\subsection{Experiments}

Three experiments were carried out.

\subsubsection{Hygienic behaviour of bees towards mite infested brood cells}

To check the ability of bees to detect and empty cells infested by $V$. destructor, two series of cells of a natural comb were compared. Treated cells were prepared by inserting, using a fine paint brush, one mite into worker cells capped 0-15 hours beforehand, through an opening in the capping which was then resealed. Control cells were obtained by opening and resealing cells without inserting a mite. The cells used for the experiment were marked on a transparent acetate sheet for subsequent recording of the number of brood cells that were emptied by the bees.

Mites used for infesting brood cells came from another bee colony. To avoid any possible interference on the removal behaviour of bees from alien scents adhering to mites, the combs used in this experiment were inserted, after treatment, into a third hive.

The removal behaviour was tested in five colonies. In each colony, the experiment was repeated twice and the data were pooled. Experiments were carried out from late May to August in two different years. From 25 to 55 cells were used per experimental group in each hive. In all, 207 cells received one mite or were just opened and resealed as controls.

The number of cells that had been emptied by bees was counted on the fifth and tenth day after the treatment.

\subsubsection{Identification of semiochemicals released by infested cells}

Compounds released in infested and uninfested worker brood cells were studied by means of SPMEGC-MS. Artificial cells were prepared by inserting a worker larva (uninfested) or a worker larva and a mite (infested) into a gelatin cell, $6.5 \mathrm{~mm}$ i.d. (Capsugel, Coni-Snap, size 1). The bee larvae and mites were obtained from cells capped 0-15 hours beforehand. The artificial cells were then transferred into an incubator and kept at $34.5 \pm 0.5{ }^{\circ} \mathrm{C}, 75 \%$ R.U.
After 24 hours, five cells of each type were sealed in an air tight vial and a SPME fiber $(100 \mu \mathrm{m}$, polydimethylsiloxane) was exposed for one hour to the volatiles emitted in the vial. The volatiles adsorbed on the SPME fiber were analyzed by means of GCMS using a Varian 3400 gas chromatograph coupled to a Varian Saturn 2000 mass spectrometer. The column $(30 \mathrm{~m} \times 0.25 \mathrm{~mm}$ ID, CP-SIL 8$)$ was maintained at $40{ }^{\circ} \mathrm{C}$ for $1 \mathrm{~min}$ then programmed at $10^{\circ} \mathrm{C} / \mathrm{min}$ to $250{ }^{\circ} \mathrm{C}$. The carrier gas was helium.

SPME-GC-MS analysis of infested and uninfested cells, as described above, was repeated six times under the same conditions using different batches of five cells for each replicate. Differences in the amount of compounds released by infested and non-infested cells were assessed by comparing the size of the corresponding peaks in SPME-GCMS analysis carried out under the same conditions.

The identity of the compounds in the extracts was confirmed by comparison of the spectra and the retention times with those of authentic standards, which were either purchased or synthesized.

To roughly estimate the amount of compounds of interest released by infested cells, uninfested gelatine cells were treated with $1 \mu \mathrm{g}$ of the compound and analyzed as described above. Then the size of the peak of interest in the SPME-GC-MS analysis of the infested cells was compared to the size of the same peak in the SPME-GC-MS analysis of the uninfested cells that had been treated with a known amount of the compound.

\subsubsection{Hygienic behaviour of bees towards cells treated with pure compounds}

The hygienic behaviour towards cells treated with one microgram of pure compounds was compared to the response towards cells treated with the solvent alone. To do this, one microliter of a solution containing $1 \mu \mathrm{g}$ of each compound in hexane was injected using a Hamilton syringe into worker cells sealed during the previous 7 hours. One $\mu \mathrm{L}$ of hexane was used to treat cells used as controls. All cells were marked on a sheet of transparent paper for data collection.

The amount of alkenes released from naturally infested cells could not be determined, so only an estimate of the amount of alkenes released from infested artificial cells was obtained. Therefore, for the dose of chemicals to be used in the bioassay, a high dose was chosen to take into account possible losses due to absorption by the wax, which is likely to occur in natural cells both after treatment and on release.

As the tested compounds were rather volatile, the number of cells that were emptied by bees in this experiment was checked only once, 5 days after treatment. 
Table I. Details on the bioassay of the compounds $(6 \mathrm{C} 15: 1=(Z)-6$-pentadecene, 7C15:1=(Z)-7-pentadecene, 8C17:1=(Z)-8-heptadecene, C15=pentadecane).

\begin{tabular}{lcccc}
\hline \multirow{2}{*}{ Compound } & $\begin{array}{c}\text { Colonies } \\
\text { used }\end{array}$ & $\begin{array}{c}\text { Replicates } \\
\text { per colony }\end{array}$ & \multicolumn{2}{c}{ Cells used } \\
\cline { 4 - 5 } & & & treated & control \\
\hline $6 \mathrm{C} 15: 1$ & 5 & $2-3$ & 211 & 213 \\
$7 \mathrm{C} 15: 1$ & 4 & $2-9$ & 384 & 386 \\
$8 \mathrm{C} 17: 1$ & 2 & 1 & 38 & 40 \\
$\mathrm{C} 15$ & 4 & 1 & 116 & 115 \\
\hline
\end{tabular}

Four compounds were tested: $(Z)-6$-pentadecene (6C15:1), (Z)-7-pentadecene (7C15:1), (Z)-8-heptadecene (8C17:1) and pentadecane (C15) (Tab. I). Pentadecene and heptadecene were tested because they appeared to be released in higher quantities when cells were infested. For pentadecene, two isomers were tested since no information on the position of double bond was available for this compound. No differences were found between infested and non-infested cells in the amount of pentadecane, so this compound was used as a control due to its similarity to pentadecene.

(Z)-6-pentadecene (6C15:1) and (Z)-8-heptadecene (8C17:1) were not commercially available, so were synthesized by standard methods.

\subsection{Statistical analysis of data}

The proportion of treated and control cells that were emptied by bees were compared using the
Mantel-Haenszel method after testing the homogeneity of the odds ratios of the replicated $2 \times 2$ tables.

\section{RESULTS}

\subsection{Removal of live mites}

Significantly more infested pupae $(P<$ 0.001) were removed than non-infested ones: on the whole, $17 \%$ of artificially infested cells were uncapped and emptied by bees after ten days compared to $4 \%$ of cells in the control group (Fig. 1). The heterogeneity among colonies was not significant $(P=0.581)$.

In one case, the heterogeneity among replicates in the same colony (colony 4$)$ was significant $(P=0.03)$.

The number of treated cells emptied by bees increased from one observation to the next. Among different hives, the removal rate after ten days varied from $12 \%$ to $22 \%$.

\subsection{Identification of compounds released from infested cells}

The SPME-GC-MS analysis of volatiles released by infested and non-infested cells were quite similar, but infested cells released more short chain unsaturated hydrocarbons. In particular, higher quantities of pentadecene

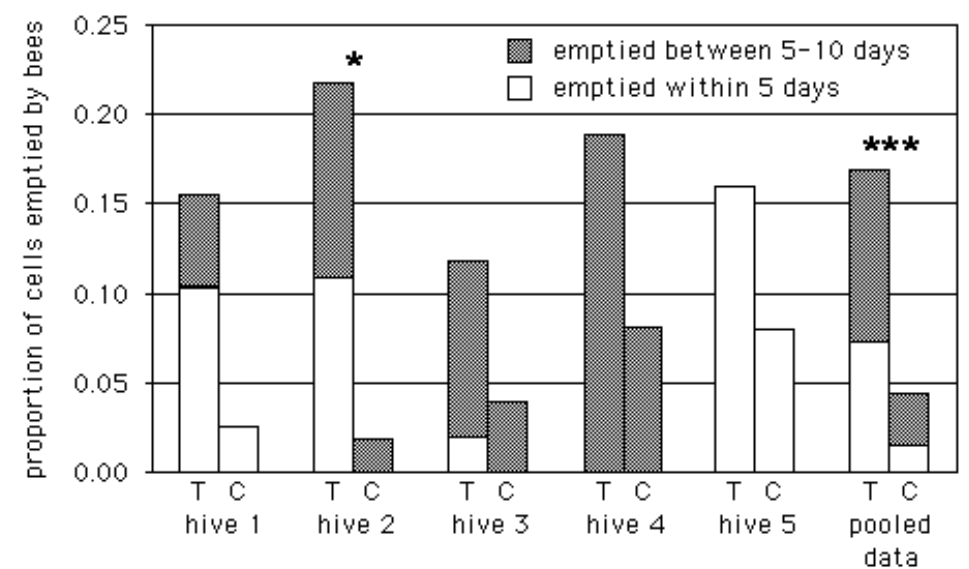

Figure 1. Hygienic behaviour of bees towards worker brood cells containing or not containing $V$. destructor. The proportion of artificially infested brood cells that were emptied by bees within 5 days and between 5-10 days was compared to the proportion of non-infested cells that were emptied within the same time span. Treated cells (T) received one live mite; control cells (C) were opened and resealed without inserting any mite. Significant differences in the proportion of infested and non infested cells emptied after 10 days are marked with asterisks $(* P<0.05, * * 0.01<P<0.05, * * * P<0.01)$. 


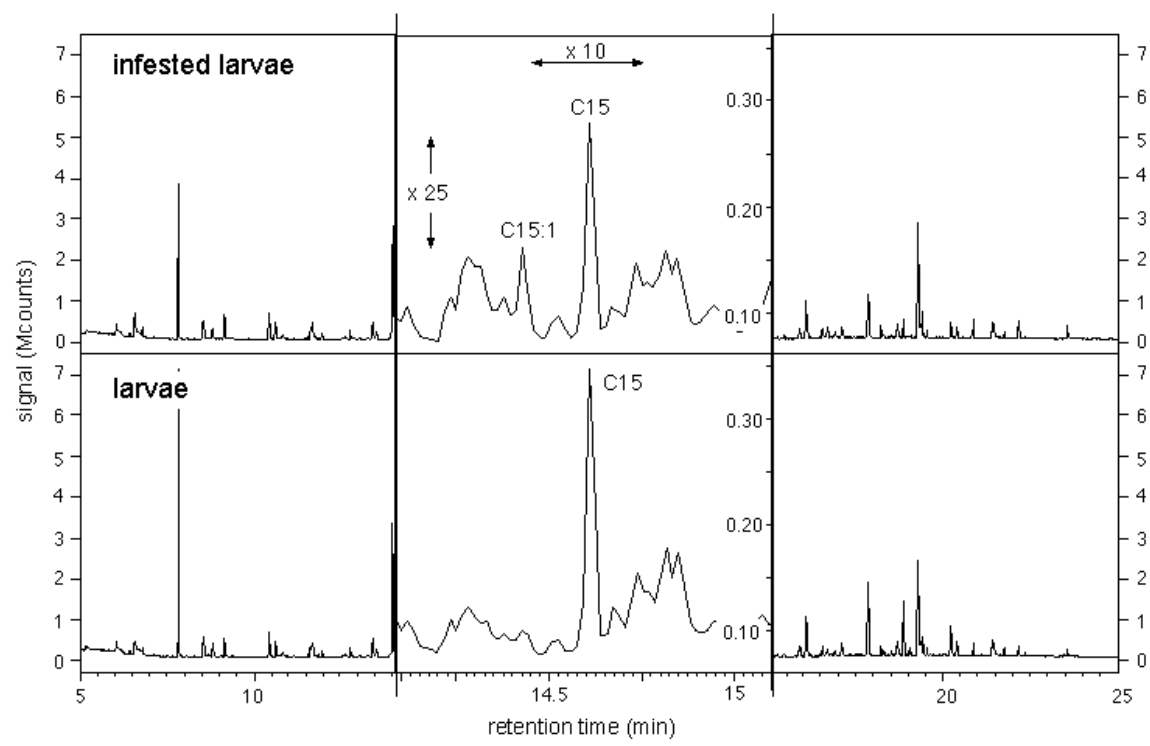

Figure 2. An example of an SPME-GC-MS analysis of volatile compounds emitted by five brood cells containing a bee larva infested or not by one mite (C15:1 = pentadecene; $\mathrm{C} 15=$ pentadecane). The horizontal and vertical scale of the central section of the GC traces were increased by 10 and 25 times respectively to show the difference in the size of the peak corresponding to pentadecene in the two cases.

$\left(\mathrm{C}_{15} \mathrm{H}_{30}\right)$ were detected in infested cells in most analysis (Fig. 2). In some analyses, differences were also found in the amount of heptadecene $\left(\mathrm{C}_{17} \mathrm{H}_{34}\right)$ released in infested cells compared to non-infested ones.

Comparison between infested cells and uninfested cells treated with a known amount of pentadecene suggested that quantities in the order of 1-10 $\mathrm{ng}$ of that compound are released by infested larvae from gelatine cells.

\subsection{Bioassay of the compounds released by infested cells}

The percentage of cells treated with $(Z)-6$ pentadecene that were emptied by bees after five days $(28 \%)$ was significantly higher $(P=$ $0.004)$ compared to that recorded in cells treated with the solvent alone (16\%) (Fig. 3). The heterogeneity among colonies was not significant $(P=0.766)$; the heterogeneity among replicates carried out within the same colony was not significant for any colony.

The isomer ( $Z$ )-7-pentadecene caused a small but not significant increase in the removal rate by bees (treated cells emptied after 5 days $=14 \%$, control cells emptied after 5 days $=10 \% ; P=0.090$ ).
Neither (Z)-8-heptadecene (treated cells emptied after 5 days: $15 \%$, control cells emptied after 5 days: 14\%) nor pentadecane (treated cells emptied after 5 days $=18 \%$, control cells removed after 5 days $=17 \%$ ) showed any significant effect on the hygienic behaviour of bees.

\section{DISCUSSION}

The results obtained when live mites were used to infest brood cells confirmed previous findings on the capability of bees to recognise infested cells and empty them (see Boecking and Spivak, 1999 for a review). The increase in the removal rate over time suggests that some olfactory cues coming from the infested larva may be involved in the recognition of infested cells by bees. In fact, as already noted by Martin et al. (2001), if the stimulating factor came from the mite itself, one would expect a more immediate response, after the introduction of the parasite into the cell.

Volatile chemicals released by infested cells were rather similar to those from uninfested brood cells with some slight differences in the amount of some short chain unsaturated 


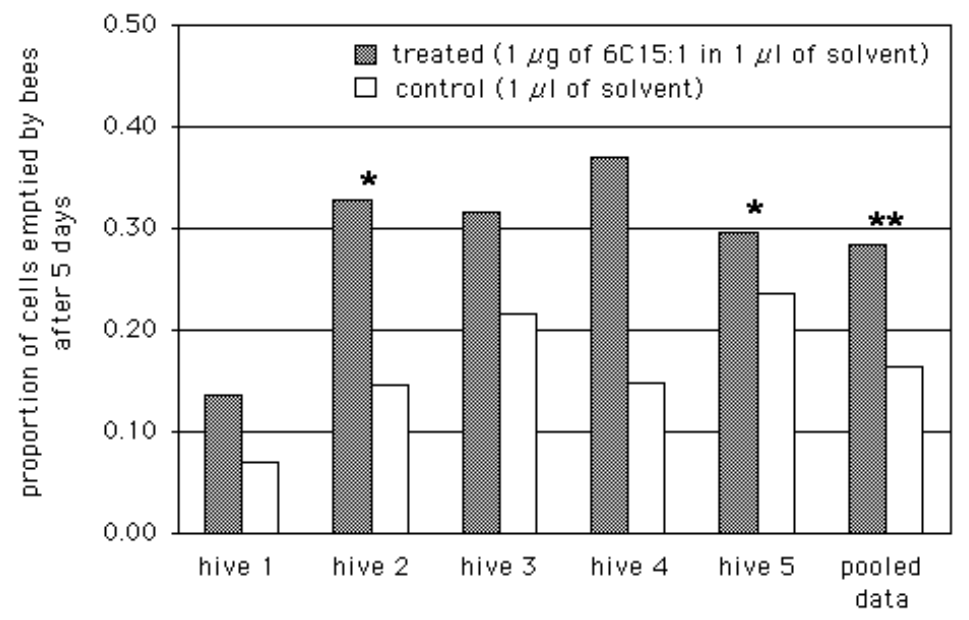

Figure 3. Hygienic behaviour of bees towards brood cells treated or not with $1 \mu \mathrm{g}$ of $(Z)$-6-pentadecene. The proportion of cells treated with $1 \mu \mathrm{g}$ of $(Z)-6$-pentadecene that were emptied by bees within 5 days was compared to the proportion of cells that received the solvent alone that were emptied in the same time span. Significant differences are marked with asterisks $(* P<0.05, * * 0.01<P<0.05, * * * P<0.01)$.

hydrocarbons. This finding was already noted by Nazzi et al. (2002); whereas Martin et al. (2002) did not study hydrocarbons shorter than 21 carbon atoms.

The volatile chemicals released by infested cells where checked only at 48 hours after infestation, thus no data are available on the chemicals released in subsequent hours. The fact that infested cells were emptied between 5-10 days could indicate that the production of the stimuli triggering removal is not restricted to the first hours after sealing.

In most of the alkenes studied by Nazzi et al. (2002) the double bond was located nine carbons from the end of the chain, whereas this information was not available for pentadecene. For this reason, $(Z)$-8-heptadecene, $(Z)$-6-pentadecene and $(Z)$-7-pentadecene were used for the bioassay of the pure compounds in the hive.

Only pentadecene significantly enhanced the removal rate of treated cells. Neither the similar alkene, heptadecene, nor the alkane with the same chain length elicited a significant removal of cells treated with these chemicals. This suggests that pentadecene may be a specific semiochemical releasing hygienic behaviour in bees. (Z)-6-pentadecene appeared to be more active than its isomer $(Z)-7$-pentadecene.

The removal of brood from cells treated with the solvent alone, observed in the bioassays of the alkenes ranged from 11 to $17 \%$.
This percent was higher than the 5\% removal of untreated control cells observed in the first experiment, suggesting that the solvent may have had an effect on the removal by bees.

The amount of alkenes released from infested natural cells is not known and only an estimate of that released from infested artificial cells was available, thus the concentration used in the bioassay reported here was arbitrarily selected. However, preliminary results showed that as little as $100 \mathrm{ng}$ per cell of $(Z)$ 7-pentadecene can cause some biological effect (treated cells removed after 5 days $=7$ I 70 , control cells removed after 5 days $=0 / 70$; $P=0.013$, Fisher exact test) while no increase in the biological activity could be achieved increasing the concentration to $10 \mu \mathrm{g}$ per cell.

Résumé - Une substance sémiochimique des cellules de couvain infestées par Varroa destructor déclenche le comportement hygiénique d'Apis melifera. La tolérance des abeilles domestiques à l'acarien Varroa destructor Anderson \& Trueman est liée à divers facteurs, parmi lesquels les réactions hygiéniques envers le couvain infesté jouent un rôle important. Les stimuli qui déclenchent le comportement hygiénique sont des signaux olfactifs émanant des cellules qui renferment le couvain infesté, mais leur identité reste inconnue.

Le but de cette étude était de vérifier l'existence de stimuli chimiques qui induisent le comportement hygiénique des abeilles envers des cellules infestées et de les identifier. La capacité des abeilles à détecter 
les cellules infestées a été confirmée en comparant le comportement hygiénique envers des cellules de couvain infestées et envers des cellules non traitées (Fig. 1). Les composés chimiques volatils libérés par les cellules infestées ont été entraînés sur des fibres SPME et analysés par chromatographie en phase gazeuse et spectrographie de masse. Les cellules infestées ont semblé libérer de plus fortes quantités d'alkènes à chaîne courte tels que le pentadécène (Fig. 2) et l'heptadécène.

L'activité biologique des substances identifiées a été testée dans la ruche en comparant le comportement hygiénique d'abeilles envers des cellules traitées avec $1 \mu \mathrm{g}$ des composés ou $1 \mu \mathrm{g}$ de solvant. Le $Z$-(6)-pentadécène a significativement augmenté le taux de cellules vidées par les abeilles (Fig. 3). Les autres composés, testés de la même façon, ont montré peu ou pas d'activité. Ce résultat peut aider à élucider le complexe des composés sémiochimiques qui joue un rôle dans la relation abeille- $V$. destructor et suggère de nouvelles stratégies pour sélectionner des souches d'abeilles ayant une forte capacité hygiénique.

Varroa destructor / composé sémiochimique / comportement hygiénique / hydrocarbure

\section{Zusammenfassung - Signalstoffe aus mit Varroa} destructor befallenen Brutzellen lösen hygienisches Verhalten bei Apis mellifera aus. Die Toleranz von Honigbienen gegen Varroa destructor Anderson \& Trueman hängt von mehreren Faktoren ab, bei denen unter anderem das hygienische Verhalten (Ausräumen der Brut) bei mit Milben befallenen Zellen eine wichtige Rolle spielen könnte. Die Reize, die hygienisches Verhalten auslösen, beruhen wahrscheinlich auf Substanzen, die von befallenen Zellen ausgehen und die olfaktorisch wahrgenommen werden. Aber ihre Identität ist noch unbekannt. Die Untersuchung hier beschäftigt sich mit der Überprüfung der Existenz solcher chemischen Reize und einer anschließenden Identifizierung der Substanzen, die das Ausräumen einer befallenen Zelle bewirken.

Die Fähigkeit der Bienen mit Milben befallene Zellen zu erkennen, wurde durch einen Vergleich des Ausräumverhaltens von künstlich infizierten mit unbehandelten Zellen bestätigt (Abb. 1). Flüchtige Chemikalien, die in befallenen Zellen abgegeben wurden, wurden mit SPME Fasern aufgefangen und mit Hilfe eines GC-MS analysiert. Befallene Zellen schienen höhere Mengen an kurzkettigen Alkenen wie Pentadecen (Abb. 2) und Heptadecen abzugeben.

Die biologische Aktivität der identifizierten Substanzen wurde im Bienenstock gemessen, indem das Ausräumverhalten durch Bienen bei Arbeiterinnenbrut in Zellen verglichen wurde, die entweder mit $1 \mu \mathrm{g}$ der Substanzen oder nur mit Lösungsmittel behandelt wurden. Z-(6)-Pentadecen erhöhte signifikant die Ausräumrate der Zellen durch Bienen (Abb. 3). Andere Verbindungen zeigten nur wenig oder keine Aktivität bei gleichen Tests. Dies Ergeb- nis mag eine Hilfe zur Aufklärung des Komplexes der Signalstoffe sein, die im Verhältnis Honigbienen und $V$. destructor eine Rolle spielen und könnte zu neuen Strategien bei der Auslese von Zuchtlinien mit höheren Ausräumraten führen.

Varroa destructor / Signalstoffe / hygienisches Verhalten / Ausräumen / Kohlenwasserstoffe

\section{REFERENCES}

Aumeier P., Rosenkranz P. (2001) Scent or movement of Varroa destructor mites does not elicit hygienic behaviour by Africanized and Carniolan honey bees, Apidologie 32, 253-264.

Boecking O., Spivak M. (1999) Behavioural defenses of honey bees against Varroa jacobsoni Oud., Apidologie 30, 141-158.

Chiesa F., Milani N., D’Agaro M. (1989) Observations of the reproductive behaviour of Varroa jacobsoni Oud.: techniques and preliminary results, in: Cavalloro R. (Ed.), Present status of varroatosis in Europe and progress in the varroa mite control, Proc. Meet. EC-Experts' Group Udine 1988, C.E.C., Luxembourg, pp. 213-222.

Gramacho K.P., Goncalves L.S., Rosenkranz P., De Jong D. (1999) Influence of body fluid from pinkilled honey bee pupae on hygienic behaviour, Apidologie 30, 367-374.

Martin C., Provost E., Roux M., Bruchou C., Crauser D., Clement J.L., Le Conte Y. (2001) Resistance of the honey bee, Apis mellifera to the acarian parasite Varroa destructor: behavioural and electroantennographic data, Physiol. Entomol. 26, 362-370.

Martin C., Provost E., Bagnères A.G., Roux M., Clement J.L., Le Conte Y. (2002) Potential mechanism for detection by Apis mellifera of the parasitic mite Varroa destructor inside sealed brood cells, Physiol. Entomol. 27, 175-188.

Masterman R., Ross R., Mesce K., Spivak M. (2001) Olfactory and behavioural response thresholds to odors of diseased brood differ between hygienic and non-hygienic honey bees (Apis mellifera L.), J. Comp. Physiol. A, Sens. Neural and Behav. Physiol. 187, 441-452.

Nazzi F., Milani N., Della Vedova G. (2002) (Z)-8Heptadecene from infested cells reduces the reproduction of Varroa destructor under laboratory conditions, J. Chem. Ecol. 28, 2181-2190.

Spivak M., Boecking O. (2001) Honey bee resistence to varroa mites, in: Webster T.C., Delaplane K.S. (Eds.), Mites of the honey bee, Dadant \& Sons, Inc., Hamilton, pp. 205-227.

Spivak M., Downey D. (1998) Field assays for hygienic behaviour in honey bees in relation to disease resistence, J. Econ. Entomol. 91, 64-70.

Spivak M., Gilliam M. (1998) Hygienic behaviour of honey bees and its application for control of brood diseases and varroa. Part II. Studies on hygienic behaviour since the Rotenbuhler era, Bee World 79, 169-186. 